\title{
Medical and laboratory assessment for regular blood donors in Sulaimani Blood Bank, Iraq
}

This article was published in the following Dove Press journal:

Patient Preference and Adherence

\author{
Hisham Arif Getta' \\ Hemn Abed Ahmad' \\ Heshu Sulaiman Rahman ${ }^{2-4}$ \\ Govand Ali Ahmed' \\ Rasedee Abdullah ${ }^{5}$ \\ 'Department of Pathology and \\ Biochemistry, College of Medicine, \\ University of Sulaimani, Sulaimani, \\ Iraq; ${ }^{2}$ Department of Clinical and \\ Internal Medicine, College of \\ Veterinary Medicine, University \\ of Sulaimani, Sulaimani, Iraq; \\ ${ }^{3}$ Department of Medical Laboratory \\ Sciences, College of Science, Komar \\ University of Science and Technology, \\ Sulaimani, Iraq; ${ }^{4}$ Department of Cell \\ and Molecular Biology, Faculty of \\ Biotechnology and Biomolecular \\ Sciences, Universiti Putra Malaysia, \\ Serdang, Selangor, Malaysia; \\ ${ }^{5}$ Department of Veterinary Laboratory \\ Diagnosis, Faculty of Veterinary \\ Medicine, Universiti Putra Malaysia, \\ Serdang, Selangor, Malaysia
}

Introduction: It has been suggested that blood donation reduces risks of developing cardiovascular diseases such as heart failure, atherosclerosis, and stroke. Although there are known benefits of blood donation, the inclination of people of the Kurdistan Region of Iraq to donate blood is not known. Therefore, the aim of this study was to determine demograpic and blood biochemical profiles of regular and first-time blood donors in the Sulaimani province of North Iraq.

Methods: A cross-sectional study was conducted at the Sulaimani Blood Bank, during the period of April 1, 2016 to March 28, 2017, on convenient samples of 100 regular and 100 firsttime blood donors. Donor particulars were obtained from blood bank records. The cholesterol, triglyceride, low-density lipoprotein, ferritin, vitamin D3, and uric acid concentrations of blood samples were determined.

Results: The main reason for blood donation by regular blood donors was headache $(45 \%)$, while for the first-timers it was to help relatives (31\%). The low-density lipoprotein and ferritin concentrations were significantly $(p=0.001)$ lower in the blood of regular donors than first-timers.

Conclusion: The study shows that regular blood donation is beneficial for the maintenance of health of donors.

Keywords: regular blood donor, first-time blood donor, lipid profile, vitamin D3, ferritin

\section{Introduction}

Around the world, donors contribute more than a million blood units each year. Even at this rate, the global demand for blood is far from being met. To ensure adequate supply, there is need to develop better organized systems to encourage blood donation and to overcome the fragile balance between supply and demand for blood. Although one of the ways to encourage blood donation is by offering remunerations, the European Union prohibits this practice. ${ }^{1}$

Blood donation has not been common practice in Iraq until recently. In fact, as late as 2010, Abdulsalam, ${ }^{2}$ during his tenure as head of the blood transfusion center of the Iraq Al-Yarmouk Teaching Hospital in Baghdad, reported that the blood transfusion services were poorly developed in Iraq. Only after recent establishment of welldesigned and high-quality services and facilities could the Iraqi Ministry of Foreign Affairs, with the cooperation of the National Blood Bank, organize a blood donation drive to support the police and army in the fight against terrorism. ${ }^{3}$

HIV, hepatitis B and C, and syphilis are known to be transmitted through blood. Thus, the World Health Organization has recommended that all donated blood be screened for these diseases. Currently, at least 13 countries worldwide do not screen for one or more of these infections. ${ }^{4}$ These countries are primarily underdeveloped 
or developing, and so blood supply is neither sufficient nor safe. In certain societies, donated blood may also need to be screened for drugs, toxic chemicals, and pesticides to ensure safety. ${ }^{5}$

Despite the availability of plasma expenders and synthetic and semi-synthetic blood products, whole blood from donors is still highly essential for the management of most health care emergencies. Although blood donation is relatively safe with hardly any harmful side effects, except for mild and temporary symptoms like weakness, nausea, and sweating, the number of donors remains low. Rarely, except in the most susceptible people will severe symptoms such as total loss of consciousness and seizures manifest. ${ }^{6}$

Blood transfusion is used to alleviate anemias. In the treatment of refractory chronic anemia, including thalassemia, sickle cell anemia, myelodysplastic syndrome, and aplastic anemia, blood transfusion is a fast, direct, and effective therapy. ${ }^{7}$ However, repeated transfusion may result in iron overload. ${ }^{8}$ Thus, in these cases, if iron-chelating therapy is not employed, the increase in iron load from hemolysis or breakdown of senescent erythrocytes would result in accumulation of iron in the liver and reticuloendothelial cells that could result in progressive and fatal cell, tissue, and organ destruction. Iron-chelating therapy would reduce the tendency for iron overload and consequential deleterious effects in long-term blood transfusion. ${ }^{9}$

There is a direct relationship between reduced frequency of cardiovascular diseases and blood donation. ${ }^{10}$ It seems that regular blood donors have lower risks for the development of myocardial infarction than nonblood donors. ${ }^{11}$ However, it is still unclear as to how blood donations would lower tendency for development of cardiovascular diseases. It is hypothesized that with blood donation, there is inhibition of lipid oxidation from the systemic reduction of iron and/or ferritin that will cause decrease in low-density lipoprotein (LDL) blood level and reducing incidence of cardiovascular diseases. ${ }^{12}$

In this study, the objective was to determine the effect of regular blood donation on the quality of life, well-being, and selected pathophysiological parameters of donors.

\section{Materials and methods Study design}

A cross-sectional study was carried out on adult males, aged 18-60 years, at the Sulaimani Blood Bank from April 1, 2016 to March 28, 2017. Convenient samples used in this study were of 2 groups: Group 1 comprised of 100 regular blood donors with 4 donations over the last 2 years or 6 donations in last 3 years and Group 2 comprised of 100 first-time donors. The participants were examined for symptoms of diseases.
The data were collected through interview of participants and with the use of a questionnaire. Participant particulars were obtained from records kept at the Blood Bank.

\section{Exclusion criteria}

Individuals with systemic diseases including hypertension, diabetes, and/or cardiovascular diseases, and those aged below 18 or above 60 years, or with hemoglobin concentration $<125 \mathrm{~g} / \mathrm{L}$ were excluded from the study.

\section{Questionnaire}

The questionnaire covers the sociodemography of donors that included age and residence, reason for and frequency of donation, body mass index (BMI), whether participants had history of chronic diseases and/or hyperlipidemia, were smokers, and/or consumed alcohol.

\section{Examination and blood collection}

Approximately $5 \mathrm{~mL}$ blood was collected from each participant for complete blood count before centrifuging at $300 \times g$ to obtain plasma. Diagnosis of polycythemia was determined from the hemogram and dyslipidemia from blood biochemical analysis. The patients were also examined for hypertension using a sphygmomanometer. The plasma ferritin and vitamin D3 concentrations were determined by radioimmunoassay using the Cobas e411 (Roche, Basel, Switzerland) immunoanalyzer. The lipid profile of 12-hour fasted donors, comprising of cholesterol, triglyceride, and LDL concentrations, and uric acid concentrations were determined by spectrophotometry using the Cobas c111 (Roche) chemistry analyzer and standard test kits (Roche).

\section{Ethical considerations}

The Ethics Committee of Sulaimani Blood Bank approved the study following the receipt of informed written consent from all of the participants. The confidentiality of participants was wholly preserved.

\section{Statistical analysis}

Statistical Package for Social Sciences version 22.0 (IBM Corporation, Armonk, NY, USA) was used. Descriptive statistics presented as mean \pm standard deviation and frequencies as percentages. Kolmogorov-Smirnov analysis verified the normality of the data set. $\chi^{2}$ test was used for comparison between categorical data, while Fishers exact test was used when expected variable were $<2 \%$ of total number of variables. Additionally, independent sample $t$-test was used to compare between means. In all statistical analysis, level of significance ( $p$-value) was set at $\alpha=0.05$. 


\section{Results}

\section{Demography}

The regular donors were significantly $(p=0.03)$ older than the first-timers. Most regular donors were 30 years or older, while $49 \%$ of first-time donors were $<30$ years old. Among the regular donors, the highest numbers were seen in those aged 30-39 years (Table 1). Most blood donors, both regulars and first-timers, were urban residents (Table 2).

\section{Lifestyle}

There is a significant ( $p=0.02$ ) association between blood donors and obesity. Most of the blood donors were at least overweight if not obese (Table 3 ). There is almost equal distribution of smokers and nonsmokers among blood donors, although there were slightly more smokers among the firsttimers. Most blood donors did not consume alcohol. The BMI of regular donors at $27.8 \pm 4.7$ was slightly $(p<0.006)$ higher than that of first-timers at 26.1 \pm 3.6 .

\section{Lipid profile}

The total plasma cholesterol level of first-time blood donors was slightly higher than regular donors, whereas the triglyceride level slightly lower (Table 4). Most blood donors showed normal plasma LDL level. However, between donor groups, the regulars had lower plasma LDL than the first-timers (Table 5).

\section{Blood biochemistry}

Most blood donors had low serum vitamin D3 and normal ferritin and uric acid levels (Table 6). However, the plasma ferritin concentration of first-time donors was significantly $(p<0.001)$ higher than regular donors (Table 4$)$.

\section{Reason for donating blood}

Among the reasons for blood donation by regulars were to relieve headaches, polycythemia, insomnia, sleepiness, neck and shoulder pains, and dizziness. The reasons for donation by the first-timers were to help relatives, because of polycythemia, headaches, sleepiness, and neck and shoulder pains. There were more first-timers without health

Table I Age distribution of male blood donors

\begin{tabular}{llllllll}
\hline \multirow{2}{*}{$\begin{array}{l}\text { Age } \\
\text { years) }\end{array}$} & \multicolumn{2}{l}{ Regular donors } & & \multicolumn{2}{l}{ Ist-time donors } & $\chi^{2}$ & p-values \\
\cline { 2 - 3 } & Number & $\%$ & & Number & $\%$ & & \\
\hline$<30$ & 29 & 29.0 & & 49 & 49.0 & 8.9 & 0.03 \\
$30-39$ & 42 & 42.0 & & 27 & 27.0 & & \\
$40-49$ & 21 & 21.0 & 18 & 18.0 & & \\
$\geq 50$ & 8 & 8.0 & 6 & 6.0 & & \\
Mean \pm SD & $35.2 \pm 8.5$ & & $32.5 \pm 9.5$ & & & \\
\hline
\end{tabular}

Abbreviation: SD, standard deviation.
Table 2 Distribution of residence male blood donors

\begin{tabular}{llllllll}
\hline Residence & \multicolumn{2}{l}{ Regular donors } & & \multicolumn{2}{l}{ Ist-time donors } & \multirow{2}{*}{$\chi^{2}$} & p-values \\
\cline { 2 - 3 } & Number & $\%$ & & Number & $\%$ & & \\
\hline Urban & 82 & 82.0 & 87 & 87.0 & 0.9 & 0.3 \\
Rural & 18 & 18.0 & & 13 & 13.0 & & \\
\hline
\end{tabular}

Table 3 Distribution of BMI and lifestyle of male blood donors

\begin{tabular}{|c|c|c|c|c|c|c|}
\hline \multirow[t]{2}{*}{ Variable } & \multicolumn{2}{|l|}{$\begin{array}{l}\text { Regular } \\
\text { donors }\end{array}$} & \multicolumn{2}{|l|}{$\begin{array}{l}\text { Ist-time } \\
\text { donors }\end{array}$} & \multirow[t]{2}{*}{$\chi^{2}$} & \multirow[t]{2}{*}{ p-values } \\
\hline & Number & $\%$ & Number & $\%$ & & \\
\hline BMI & & & & & 7.7 & 0.02 \\
\hline Normal & 22 & 22.0 & 35 & 35.0 & & \\
\hline Overweight & 54 & 54.0 & 54 & 54.0 & & \\
\hline Obese & 24 & 24.0 & 11 & 11.0 & & \\
\hline Smoking & & & & & 0.5 & 0.4 \\
\hline Yes & 57 & 57.0 & 52 & 52.0 & & \\
\hline No & 43 & 43.0 & 48 & 48.0 & & \\
\hline Alcohol consumption & & & & & 0.09 & 0.7 \\
\hline Yes & 29 & 29.0 & 27 & 27.0 & & \\
\hline No & 71 & 71.0 & 73 & 73.0 & & \\
\hline
\end{tabular}

Abbreviation: BMI, body mass index.

Table 4 Physical and plasma biochemical parameters of male blood donors

\begin{tabular}{|c|c|c|c|c|}
\hline \multirow[t]{2}{*}{ Variable } & \multirow{2}{*}{$\begin{array}{l}\text { Regular } \\
\text { donors } \\
\text { Mean } \pm \text { SD }\end{array}$} & \multirow{2}{*}{$\begin{array}{l}\text { Ist-time } \\
\text { donors } \\
\text { Mean } \pm \text { SD }\end{array}$} & \multirow[t]{2}{*}{ t-test* } & \multirow[t]{2}{*}{$p$-values } \\
\hline & & & & \\
\hline Age (years) & $35.2 \pm 8.5$ & $32.5 \pm 9.5^{\mathrm{a}}$ & 2.1 & 0.04 \\
\hline BMI & $27.8 \pm 4.7$ & $26.1 \pm 3.6^{\mathrm{a}}$ & 2.7 & 0.006 \\
\hline Cholesterol (mmol/L) & $197.6 \pm 43.8$ & $209.5 \pm 45.6$ & 1.8 & 0.06 \\
\hline Triglycerides (mmol/L) & $250 \pm 134$ & $216 \pm 114$ & 1.9 & 0.06 \\
\hline $\mathrm{LDL}(\mathrm{mmol} / \mathrm{L})$ & $93.3 \pm 32.8$ & $105.7 \pm 34.7^{\mathrm{a}}$ & 2.5 & 0.01 \\
\hline Ferritin (ng/L) & $78.6 \pm 75.3$ & $158.8 \pm 99.1^{a}$ & 6.4 & $<0.001$ \\
\hline Vitamin D3 (U/L) & $19.6 \pm 5.9$ & $18.5 \pm 6.6$ & 0.8 & 0.4 \\
\hline Uric acid $(\mu \mathrm{m} / \mathrm{L})$ & $6.3 \pm 1.8$ & $6.1 \pm 1.5$ & 0.7 & 0.4 \\
\hline
\end{tabular}

Notes: *Student's $t$-test was used for measuring the significance between regular blood donors and Ist-time blood donors for the listed variables. ${ }^{a}$ Significant difference between Ist-time donors compared to regular donors.

Abbreviations: BMI, body mass index; LDL, low-density lipoprotein; SD, standard deviation.

Table 5 Distribution of lipid profile in regular male blood donors and Ist-time male donors

\begin{tabular}{|c|c|c|c|c|c|c|}
\hline \multirow[t]{2}{*}{ Variable } & \multicolumn{2}{|l|}{$\begin{array}{l}\text { Regular } \\
\text { donors }\end{array}$} & \multicolumn{2}{|l|}{$\begin{array}{l}\text { Ist-time } \\
\text { donors }\end{array}$} & \multirow[t]{2}{*}{$\chi^{2}$} & \multirow[t]{2}{*}{ p-values } \\
\hline & Number & $\%$ & Number & $\%$ & & \\
\hline Cholesterol & & & & & 2.0 & 0.1 \\
\hline Normal & 54 & 54.0 & 44 & 44.0 & & \\
\hline High & 46 & 46.0 & 56 & 56.0 & & \\
\hline Triglycerides & & & & & 2.8 & 0.09 \\
\hline Normal & 43 & 43.0 & 55 & 55.0 & & \\
\hline High & 57 & 57.0 & 45 & 45.0 & & \\
\hline LDL & & & & & $3.7^{\mathrm{a}}$ & 0.05 \\
\hline Normal & 99 & 99.0 & 94 & 94.0 & & $\mathrm{OR}=6.3$ \\
\hline High & 1 & 1.0 & 6 & 6.0 & & $\mathrm{Cl}=\{0.7-53.4\}$ \\
\hline
\end{tabular}

Note: aishers exact test.

Abbreviations: $\mathrm{Cl}$, confidence interval; $\mathrm{LDL}$, low-density lipoprotein; OR, odds ratio. 
Table 6 Distribution of male blood donors with normal and abnormal plasma vitamin D3, ferritin, and uric acid concentrations

\begin{tabular}{|c|c|c|c|c|c|c|}
\hline \multirow[t]{2}{*}{ Variable } & \multicolumn{2}{|l|}{$\begin{array}{l}\text { Regular } \\
\text { donors }\end{array}$} & \multicolumn{2}{|l|}{$\begin{array}{l}\text { Ist-time } \\
\text { donors }\end{array}$} & \multirow[t]{2}{*}{$\chi^{2}$} & \multirow[t]{2}{*}{$p$-values } \\
\hline & Number & $\%$ & Number & $\%$ & & \\
\hline Vitamin D3 & & & & & $0.1^{a}$ & 0.7 \\
\hline Low & 95 & 95.1 & 96 & 96.0 & & \\
\hline $\begin{array}{l}\text { Normal } \\
(>30 \mathrm{ng} / \mathrm{mL})\end{array}$ & 5 & 5.0 & 4 & 4.0 & & \\
\hline Serum ferritin & & & & & $21.2^{\mathrm{a}}$ & $<0.001$ \\
\hline Low & 25 & 25.0 & 3 & 3.0 & & \\
\hline $\begin{array}{l}\text { Normal } \\
(30-400 \mathrm{ng} / \mathrm{L})\end{array}$ & 74 & 74.0 & 93 & 93.0 & & \\
\hline High & I & 1.0 & 4 & 4.0 & & \\
\hline Serum uric acid & & & & & 1.8 & 0.1 \\
\hline $\begin{array}{l}\text { Normal } \\
(3.3-7 \mathrm{mg} / \mathrm{dL})\end{array}$ & 73 & 73.0 & 81 & 81.0 & & \\
\hline High & 27 & 27.0 & 19 & 19.0 & & \\
\hline
\end{tabular}

Note: aFishers exact test.

reasons than regular donors that volunteered to donate blood (Table 7).

\section{Discussion}

There is a serious blood shortage of blood donors, even in some of large cities, despite the desperate need for blood in medical practice. ${ }^{13} \mathrm{~A}$ high proportion of blood donation comes from donors with health issues or those that have relatives that require blood to compensate for loss during surgery or to treat anemias.

We determined the demography and physical and health of characteristics of regular and first-time blood donors. The study showed that there were more regular blood donors among people aged at least 30 years. Similar in the USA, older people aged from 40 to 49 years tended to donate more units of blood than the young. ${ }^{14}$ From 1996 to 2005,

Table 7 Reasons for donation by the male blood donors

\begin{tabular}{|c|c|c|c|c|c|c|}
\hline \multirow[t]{2}{*}{$\begin{array}{l}\text { Causes of } \\
\text { donation }\end{array}$} & \multicolumn{2}{|l|}{$\begin{array}{l}\text { Regular } \\
\text { donors }\end{array}$} & \multicolumn{2}{|l|}{$\begin{array}{l}\text { I st-time } \\
\text { donors }\end{array}$} & \multirow[t]{2}{*}{$\chi^{2}$} & \multirow[t]{2}{*}{$p$-values } \\
\hline & Number & $\%$ & Number & $\%$ & & \\
\hline Headache & 45 & 45.0 & 18 & 18.0 & $65.5^{a}$ & $<0.001$ \\
\hline Polycythemia & 15 & 15.0 & 20 & 20.0 & & \\
\hline Volunteer & 10 & 10.0 & 23 & 23.0 & & \\
\hline Insomnia & 9 & 9.0 & 0 & - & & \\
\hline Sleepiness & 7 & 7.0 & 2 & 2.0 & & \\
\hline $\begin{array}{l}\text { Neck and } \\
\text { shoulder pain }\end{array}$ & 5 & 5.0 & 2 & 2.0 & & \\
\hline Dizziness & 4 & 4.0 & 0 & - & & \\
\hline $\begin{array}{l}\text { Blood donation } \\
\text { for relatives }\end{array}$ & 0 & - & 31 & 31.0 & & \\
\hline Others & 5 & 5.0 & 4 & 4.0 & & \\
\hline
\end{tabular}

Note: ${ }^{\mathrm{a}}$ ishers exact test. however, after adjusting to population trend, the number of donors decreased by approximately $10 \%{ }^{15}$

Repeat blood donors also showed reduction in BMI, blood lipid, and cholesterol levels. Thus, regular blood donation is beneficial to health because the lowering of plasma total cholesterol and LDL levels reduce risk of developing cardiovascular diseases. ${ }^{16}$

Obesity-related hypertension is on the increase worldwide, and the number of adults with hypertension is predicted to increase by $60 \%$ by year $2025 .{ }^{17}$ Hypertension often causes migraine headaches. Our study showed that headache was the main reason for blood donation among regulars, while for first-time donors it was to help relatives. This finding is in agreement with that of another study conducted in $\operatorname{Iran}^{18}$ which concluded that headache was the main reason of regular blood donation. Although it was not determined in our study, it is possible that most donors with headaches may have had hypertension. It seems, according to a recent study, that blood donation is beneficial because it decreases the blood pressure of hypertensive regular donors. ${ }^{19}$

Our study showed that obesity was significantly associated with regular blood donations. Obesity is also generally associated with middle age, and this is also true for blood donors. ${ }^{20}$ It was shown that phlebotomy will reduce body iron stores, lower blood pressure, and reduce the risk of developing hyperglycemia and cardiovascular diseases, characteristics most often associated with obesity. ${ }^{21}$ People with higher BMI, advanced age, and low physical activity tend to show unfavorable plasma lipid profile that may predispose them to cardiovascular diseases. Thus, obese people may have greater inclination to donate blood because of these benefits. ${ }^{19}$

Plasma LDL is one of the biomarkers of cardiovascular events, especially coronary heart disease. ${ }^{18}$ However, among the parameters, plasma LDL/high-density lipoprotein (HDL) ratio is a better indicator of risk for coronary heart disease than either plasma LDL or HDL alone. ${ }^{22}$ Our study showed that regular blood donors had lower plasma LDL level than the first-timers. This finding is consistent with that shown by earlier studies in Nigeria, ${ }^{23}$ Indonesia, ${ }^{24}$ and India. ${ }^{25}$ The effect on lowering plasma LDL with blood donation was also shown in a study in Ethiopia. ${ }^{26}$ That study showed blood donors had significantly lower LDL than the reference values. However, not all studies showed that blood donation is associated with lower risk of cardiovascular diseases. For example, in the USA, it was shown that there is no significant association between blood donation or risk of myocardial infarction. ${ }^{27}$ However, in our study, the low plasma LDL 
among regular blood donors is presumed to help reduce incidence of cardiovascular diseases.

The mean blood ferritin level seems to decrease with increase in number donations, ${ }^{28}$ which is suggested to be associated with reduced iron stores and risk of myocardial infarction. ${ }^{29}$ In fact, high serum ferritin is strongly associated with cardiac disease or fatal coronary heart disease. ${ }^{30}$ In our study, the plasma ferritin was lower in regular than first-time donors. Similar studies conduct in Malaysia ${ }^{28}$ and India ${ }^{31}$ showed regular blood donors to have low serum iron concentrations, which also suggest that frequent blood donations reduce iron storage.

Similar to other cross-sectional studies related to blood donation, the limitation points to this research that might strongly affecting the results of this study include not assessing the temporal relationship, the availability of only a single blood bank in the city, and the selection bias.

\section{Conclusion}

In conclusion, the study shows that regular blood donation is beneficial for the improvement of lipid profile and cardiovascular diseases. There were fewer regular blood donors with high LDL concentrations than first-timers. The study also shows that headache was the predominant reason for donating blood among regulars, while blood donation for relatives was the main reason for donation among first-time donors. The serum ferritin levels, which are a reflection of storage iron, were lower among regular than first-time blood donors. The elderly and obese were the more frequent blood donors.

\section{Acknowledgments}

The authors would like to thank the College of Medicine, University of Sulaimani, Iraq, for providing technical knowledge, assistance, and facilities for this study. Special thanks to the Ministry of Higher Education of Kurdistan, Iraq, for funding this project. The authors also thank the staff of Sulaimani Blood Bank and Ria Laboratory for their assistance in the collection and processing of blood samples.

\section{Disclosure}

The authors report no conflicts of interest in this work.

\section{References}

1. Kalibatas V, Kalibatiené L. The results of nucleic acid testing in remunerated and non-remunerated blood donors in Lithuania. Blood Transfus. 2014;12(Suppl 1):s58-s62.

2. Abdulsalam AH. Blood transfusion services in Iraq; an unfortunate field. Turk J Hematol. 2010;27(2):128-129.
3. Iraqi Ministry of Foreign Affairs. Iraqi ministry of foreign affairs organizes blood donation campaign to support the Iraqi forces in its war against Da' esh terroristic gangs. Available from: http://www.mofa. gov.iq/en/news.php?articleid=1468. Accessed April 24, 2018.

4. World Health Organization. Blood Safety and Availability. Geneva: World Health Organization; 2017. Available from: http:/www.who. int/mediacentre/factsheets/fs279/en/. Accessed April 24, 2018.

5. Krewski D, Acosta D Jr, Andersen M, et al. Toxicity testing in the $21 \mathrm{st}$ century: a vision and a strategy. J Toxicol Environ Health B Crit Rev. 2010;13(2-4):51-138.

6. Raju S, Singh BD, Verma NS, et al. Study of body mass index (BMI) and lipid profile of blood donors of north Indian population: a cross sectional study. Int J Biomed Res. 2015;6(60):425-428.

7. Brittenham GM. Iron-chelating therapy for transfusional iron overload. New England J Med. 2011;364(2):146-156.

8. Mumtaz Z, Bowen S, Mumtaz R. Meanings of blood, bleeding and blood donations in Pakistan: implications for national vs global safe blood supply policies. Health Policy Plan. 2012;27(2):147-155.

9. Gao C, Li L, Chen B, et al. Clinical outcomes of transfusion-associated iron overload in patients with refractory chronic anemia. Patient Prefer Adherence. 2014;8:513-517.

10. Holsworth RE, Cho YI, Weidman JJ, Sloop GD, Cyr JA. Cardiovascular benefits of phlebotomy: relationship to changes in hemorheological variables. Perfusion. 2014;29(2):102-116.

11. Salonen JT, Tuomainen TP, Salonen R, Lakka TA, Nyyssonen K. Donation of blood is associated with reduced risk of myocardial infarction: the Kuopio Ischaemic Heart Disease Risk Factor Study. Am J Epidemiol. 1998;148(5):445-451.

12. Houschyar KS, Lüdtke R, Dobos GJ, et al. Effects of phlebotomyinduced reduction of body iron stores on metabolic syndrome: results from a randomized clinical trial. BMC Med. 2012;10(1):54-61.

13. Fatusi AO. Public health leadership, policy development and the Nigerian health system. Paper Presented at: The Induction Program of the Institute for Government Research Leadership Technology; March 1, 2015; Abuja, Nigeria.

14. Shaz BH, Hillyer KL, Hillyer CD, Schreiber GB, Hillyer CD. Demographic patterns of blood donors and donations in a large metropolitan area. J Natl Med Assoc. 2011;103(4):351-357.

15. Zou S, Musavi F, Notari EP 4th, Fang CT; ARCNET Research Group. Changing age distribution of the blood donor population in the United States. Transfusion. 2008;48(2):251-257.

16. Adias TC, Igwilo AC, Jeremiah ZA. Repeat whole blood donation correlates significantly with reductions in BMI and lipid profiles and increased gamma glutamic transferase (GGT) activity among Nigerian blood donors. Open J Blood Dis. 2012;2(4):90-94.

17. Narkiewicz K. Obesity and hypertension - the issue is more complex than we thought. Nephrol Dial Transplant. 2005;21(2):264-267.

18. Abolghasemi H, Hosseini-Divkalayi NS, Seighali F. Blood donor incentives: a step forward or backward. Asian J Transfus Sci. 2010;4(1): 9-13.

19. Kamhieh-Milz S, Kamhieh-Milz J, Tauchmann Y, et al. Regular blood donation may help in the management of hypertension: an observational study on 292 blood donors. Transfusion. 2016;56(3):637-644.

20. Murphy EL, Schlumpf K, Wright DJ, et al. BMI and obesity in US blood donors: a potential public health role for the blood centre. Public Health Nutr. 2012;15(6):964-971.

21. Uche EI, Adediran A, Damulak OD, Adeyemo TA, Akinbami AA, Akanmu AS. Lipid profile of regular blood donors. J Blood Med. 2013; $4: 39-42$.

22. Panagiotakos DB, Toutouzas PK. Importance of LDL/HDL cholesterol ratio as a predictor for coronary heart disease events in patients with heterozygous familial hypercholesterolaemia: a 15-year follow-up (1987-2002). Curr Med Res Opin. 2003;19(2):89-94.

23. Ugwuja EI, Ogbonna NC, Nwibo AN, Onimawo IA. Overweight and obesity, lipid profile and atherogenic indices among civil servants in Abakaliki, South Eastern Nigeria. Ann Med Health Sci Res. 2013; 3(1):13-18. 
24. Rusdiah W, Muhiddin R, Arif M. Lipid profile analysis on regular and non-regular blood donors. Indonesian J Clin Pathol Med Lab. 2017; 23(1):27-30.

25. Bharadwaj RS. A study of lipid profiles among male voluntary blood donors in Chennai city. Indian J Community Med. 2005;30(1): 16-17.

26. Eshete EA, Weldemariam TZ. Hematological and lipid profiles of blood donors at Red Cross Center Addis Ababa. Ethiop Med J. 2016; 54(1):21-25.

27. Ascherio A, Rimm EB, Giovannucci E, Willett WC, Stampfer MJ. Blood donations and risk of coronary heart disease in men. Circulation. 2001;103(1):52-57.
28. Nadarajan VS, Eow GI. Anaemia and iron status among blood donors in a blood transfusion unit in Malaysia. Malays J Pathol. 2002; 24(2):99-102.

29. Holay MP, Choudhary AA, Suryawanshi SD. Serum ferritin - a novel risk factor in acute myocardial infarction. Indian Heart J. 2012; 64(2):173-177.

30. Ellervik C, Marott JL, Tybjærg-Hansen A, Schnohr P, Nordestgaard BG. Total and cause-specific mortality by moderately and markedly increased ferritin concentrations: general population study and metaanalysis. Clin Chem. 2014;60(11):1419-1428.

31. Mahida VI, Bhatti A, Gupte SC. Iron status of regular voluntary blood donors. Asian J Transfus Sci. 2008;2(1):9-12.

\section{Publish your work in this journal}

Patient Preference and Adherence is an international, peer-reviewed, open access journal that focuses on the growing importance of patient preference and adherence throughout the therapeutic continuum. Patient satisfaction, acceptability, quality of life, compliance, persistence and their role in developing new therapeutic modalities and compounds to optimize clinical outcomes for existing disease states are major areas of interest for the journal. This journal has been accepted for indexing on PubMed Central. The manuscript management system is completely online and includes a very quick and fair peer-review system, which is all easy to use. Visit http://www dovepress.com/testimonials.php to read real quotes from published authors.

Submit your manuscript here: http://www.dovepress.com/patient-preference-and-adherence-journal 